PAweŁ CZAPlińsKi

Akademia Pomorska w Słupsku

AnNA STAWARSKA

Scania Production Słupsk S.A.

\title{
Przejawy procesu globalizacji w sferze produkcji na przykładzie Scania Production Słupsk S. A.
}

\section{WPROWADZENIE}

Globalizacja w odniesieniu do przedsiębiorstw może oznaczać zaawansowane umiędzynarodowienie ich działalności, które będzie polegać na funkcjonalnej integracji rozproszonych po świecie jednostek organizacyjnych (Stryjakiewicz 1999). Założenie to najpełniej realizowane jest przez przedsiębiorstwa, które sukcesywnie i konsekwentnie rozszerzają zasięg swego działania poprzez łączenie się w różne formy organizacyjne (np. korporacje transnarodowe), które dysponując ogromnymi zasobami i tworzą liczne, zagraniczne filie lub oddziały (Zorska 2006).

Sens ich funkcjonowania jest ściśle związany z poszukiwaniem przez korporacje transnarodowe tanich zasobów, które znacząco wpływają na optymalizację czynników produkcji, a także z poszukiwaniem chłonnych rynków zbytu, determinujących warunki lokalizacji nie tylko jednostek produkcyjnych. Ponadto ważne dla korporacji są liczne ulgi inwestycyjne czy łagodniejsze normy ochrony środowiska, dzięki którym w stosunkowo prosty sposób można uzyskać przewagę konkurencyjną.

Powstawanie filii i oddziałów korporacji międzynarodowych korzystne jest również dla lokalnego środowiska społeczno-gospodarczego, ponieważ każda taka inwestycja w sposób oczywisty powoduje napływ środków pieniężnych, które pozwalają na rozpoczęcie lub utrzymanie produkcji. Warto podkreślić, że obok nakładów finansowych następuje także transfer technologiczny, organizacyjny, zarządczy oraz logistyczny, którego skutki są zwykle bardziej doniosłe aniżeli samej inwestycji (Pakulska, Poniatowska-Jaksch 2009).

Funkcjonowanie jednostek produkcyjnych będących oddziałami korporacji transnarodowych wpływa również korzystnie na ożywienie lokalnej działalności gospodarczej, rozwój lokalnego rynku pracy, rozbudowę kontaktów zagranicznych lokalnych przedsiębiorstw, rozwój systemu informacji gospodarczej, wreszcie na aktywizację lokalnego biznesu, który może powielać działania korporacji, co prowadzi do tzw. efektu naśladownictwa (Gierańczyk, Stańczyk 2003). 
W świetle powyższych rozważań podjęto próbę charakterystyki funkcjonowania przedsiębiorstwa Scania Production Słupsk S.A. wchodzącego w skład szwedzkiego koncernu Scania AB.

\section{SCANIA JAKO KONCERN TRANSNARODOWY}

Scania AB to jeden z najstarszych producentów pojazdów mechanicznych na świecie, który współcześnie specjalizuje się w produkcji ciężkich pojazdów samochodowych. Od powstania przedsiębiorstwa w 1891 r. ma swoją siedzibę w Szwecji w Södertälje. Jest to nie tylko główny ośrodek decyzyjny, ale również miejsce rozwoju kadr oraz centrum badań i rozwoju. Skupia on 21,0\% ogółu pracujących w koncernie. Swoją działalność serwisową i handlową koncern prowadzi w Europie, Ameryce Południowej, Afryce, Azji i Australii. Scania AB reprezentowana jest prawie w 100 krajach, przez 164 dealerów w 1237 punktach serwisowych. Jednostki produkcyjne rozmieszczone są w 8 krajach Europy i Ameryki Południowej (tab. 1). Koncern zatrudniał w 2006 r., ogółem 13085 pracowników ${ }^{1}$, z tego w Europie 9476 osób, to jest 72,4\%. Ponadto około 10000 osób pracuje w niezależnych biurach sprzedaży i stacjach serwisowych związanych z koncernem.

Tab. 1. Rozmieszczenie zakładów produkcyjnych koncernu Scania AB na świecie według liczby pracujących oraz asortymentu produkcji w 2006 roku

\begin{tabular}{|c|c|c|c|}
\hline \multirow{2}{*}{ Lokalizacja zakładu } & \multirow{2}{*}{ Produkowany asortyment } & \multicolumn{2}{|c|}{ Pracujący } \\
\hline & & w osobach & $\mathrm{w} \%$ \\
\hline Sao Paulo (Brazylia) & $\begin{array}{l}\begin{array}{l}\text { silniki, skrzynie biegów, osie podwoziowe, cią- } \\
\text { gniki siodłowe i podwozia autobusowe }\end{array} \\
\end{array}$ & 2865 & 21,9 \\
\hline Södertälje (Szwecja) & $\begin{array}{l}\text { komponenty, silniki, ciagniki siodłowe } \\
\text { i podwozia autobusowe }\end{array}$ & 2744 & 21,0 \\
\hline Oskarhamn (Szwecja) & kabiny ciężarówek & 1707 & 13,0 \\
\hline Zwolle (Holandia) & montaż ciągników siodłowych & 1486 & 11,4 \\
\hline Falun (Szwecja) & osie podwoziowe & 843 & 6,4 \\
\hline Tucuman (Argentyna) & komponenty do produkcji skrzyń biegów & 744 & 5,7 \\
\hline Słupsk (Polska) & \begin{tabular}{|l}
$\begin{array}{l}\text { montaż autobusów oraz podwozi } \\
\text { autobusowych }\end{array}$ \\
\end{tabular} & 688 & 5,2 \\
\hline Luleå (Szwecja) & komponenty & 620 & 4,7 \\
\hline Sibbhult (Szwecja) & skrzynie biegów & 612 & 4,7 \\
\hline Angers (Francja) & montaż ciągników siodłowych & 560 & 4,3 \\
\hline St. Petersburg (Rosja) & montaż autobusów & 216 & 1,7 \\
\hline \multicolumn{2}{|l|}{ Razem } & 13085 & 100,0 \\
\hline
\end{tabular}

Źródło: Scania Annual Report 2006, Scania CV AB, Södertälje, Sweden 2007

1 Dane na koniec 2006 r., dotyczą tylko pracowników zatrudnionych na umowę o pracę. 
Scania AB to spółka akcyjna, która weszła na giełdę w Sztokholmie i Nowym Jorku² w 1996 r. Spowodowało to zmiany w strukturze własności spółki. Kluczowe zmiany miały nastapić w 2006 r, kiedy o kupno udziałów starał się niemiecki koncern MAN AG. Jednak większość udziałowców nie wyraziła zgody na odsprzedanie udziałów ${ }^{3}$. Dopiero w roku 2008 doszło do zasadniczych zmian własnościowych. Obecnie dotychczasowi udziałowcy koncernu Scania AB posiadają 40\% udziałów, a pozostałe $60 \%$ należy do niemieckiej grupy kapitałowej Volksvagen AG.

Jak już wspomniano, Scania AB, to jeden z największych koncernów produkujących ciężkie pojazdy samochodowe. Głównymi globalnymi konkurentami rynkowym pojazdów marki Scania są Mercedes Benz należący do koncernu Daimler AG, MAN koncernu Maschinenfabrik Augsburg-Nürnberg Aktiengesellschaft oraz Volvo grupy Volvo Group $\mathrm{AB}$, ponadto marki DAF, Iveco i Renault (ryc. 1).

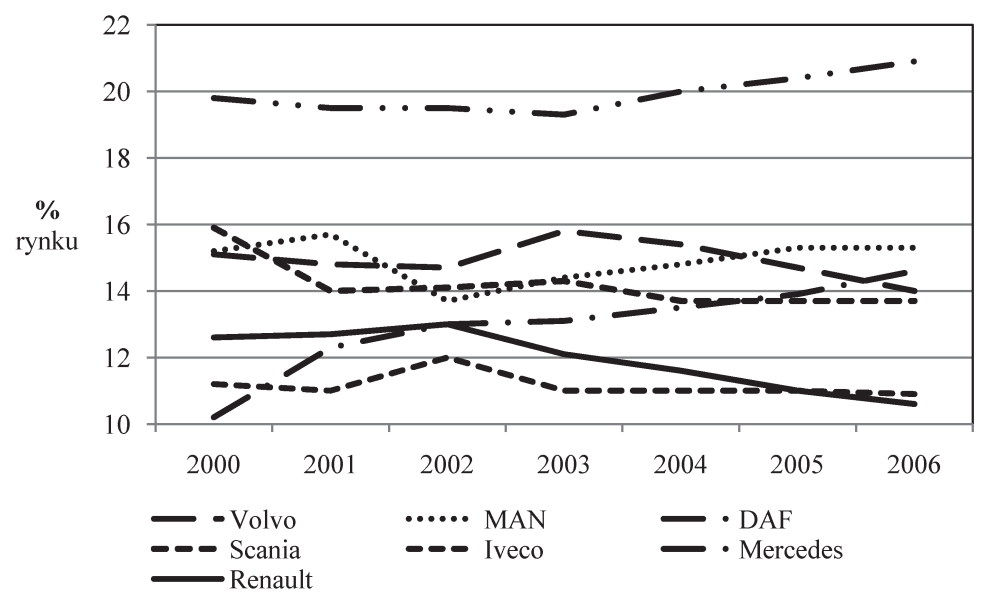

Ryc. 1. Pozycja konkurencyjna Scania $\mathrm{AB}$ według dostarczonych na rynek ciężarówek w latach 2000-2006

Źródło: Scania Annual Report 2006, Scania CV AB, Södertälje, Sweden 2007

Jak wynika z analizy, koncern Scania AB znajduje się w czołówce producentów ciężarówek na świecie. W 2006 r. dostarczył on swoim odbiorcom ponad 60 tys. ciężarówek, tym samym jego udział w rynku światowym wyniósł $13,7 \%$.

\section{ScAnia Production SŁuPsk S.A}

Działalność koncernu Scania AB w Polsce rozpoczęła się w 1992 r. ${ }^{4}$, kiedy został otwarty zakład produkcyjny w Słupsku. Do dzisiaj pozostaje on jedynym zakładem produkcyjnym koncernu w Polsce. Głównym czynnikiem, który zadecydował o lokalizacji inwe-

2 Scania Annual Report 2006, Scania CV AB, Södertälje Sweden 2007.

${ }^{3}$ Informacje uzyskane od Dyrektora Finansowego Anny Siwiak podczas wywiadu przeprowadzonego w dniu 28.04.2008.

4 Dopiero w 1995 r. roku działalność rozpoczęła spółka Scania Polska S.A. w Nadarzynie, która przejęła funkcję generalnego importera i przedstawiciela w Polsce. W pierwszych latach swojej działalności stworzono sieć 29 stacji dealerskich i serwisowych na terytorium całej Polski. 
stycji w Słupsku, było funkcjonowanie w mieście Komunalnego Przedsiębiorstwa Naprawy Autobusów Kapena. Utworzona spółka joint-venture Scania-Kapena S.A. wykorzystała dotychczasowy profil działalności i związany z nim park maszynowy oraz doświadczenie i umiejętności przy relatywnie niskich kosztach pracy polskiego udziałowca. Dużą rolę odegrała również dostępność komunikacyjna Słupska i korzystne położenie geograficzne względem Szwecji i potencjalnych rynków Europy Środkowo-Wschodniej.

Z przeprowadzonych badań dotyczących czynników lokalizacji Scania Production Słupsk S.A. wynika, że w okresie funkcjonowania przedsiębiorstwa na terenie miasta w latach 19922007 zaszły dość istotne zmiany co do istotności czynników (Czapliński, Musiałek 2007).

W 1992 r. liczba kluczowych czynników lokalizacyjnych była znacznie mniejsza aniżeli ta, która współcześnie decyduje o kontynuowaniu produkcji (ryc. 2). W podjęciu decyzji o rozpoczęciu działalności w Polsce przez koncern Scania AB, decydującą rolę odegrał czynnik instytucjonalny, a w szczególności przyjazność Urzędu Wojewódzkiego w Słupsku oraz wsparcie pozostałych władz lokalnych, w tym władz miasta. Ponadto nie bez znaczenia okazały się dostępność przestrzeni w obszarze miejskim, dogodne położenie komunikacyjne, w tym bliskość portów morskich, dostępność do branżowego szkolnictwa zawodowego oraz duża koncentracja ludności na obszarze miejskim.

W 2007 r. najważniejszym czynnikiem lokalizacji dla koncernu okazała się dostępność do telefonii przewodowej i Internetu, której zadaniem jest usprawnianie przepływu informacji między siedzibą zarządu koncernu w Szwecji, przedsiębiorstwem, dostawcami oraz pozostałymi oddziałami Scania AB.

Ponadto według opinii kadry zarządzającej słupskim przedsiębiorstwem decydującą rolę odgrywały takie czynniki, jak bliskość kooperantów i dostawców, obecność firm z udziałem kapitału zagranicznego, dobra dostępność sieci telefonii bezprzewodowej, koszty wynajmu lub kupna istniejących obiektów, a także wizerunek miasta, bliskość szkół wyższych oraz koszty energii.

Porównując istotność czynników lokalizacji w obu omawianych przekrojach czasowych, zauważa się, że istnieje pewna grupa czynników, która była i jest ważna przy podejmowaniu decyzji lokalizacyjnych. Są to: dostępność i bliskość portów morskich oraz dwa czynniki społeczne - koncentracja ludności w dużych miastach oraz wsparcie władz lokalnych.

Jak już wspomniano, w 1992 r. utworzono spółkę joint-venture Scania-Kapena S.A., w której koncern Scania AB stał się właścicielem 65\% udziałów, a pozostałe 35\% udziałów przypadło Komunalnemu Przedsiębiorstwu Naprawy Autobusów Kapena. Koncern Scania AB zawiązując spółkę joint-venture zapewnił wzrost zatrudnienia wraz ze wzrostem produkcji oraz remont i modernizację zakupionych nieruchomości. Warto odnotować, że 1993 r. spółka stała się pierwszym w Polsce zakładem montażu ciężarówek obcej marki. W momencie rozpoczęcia działalności dzierżawiła ona od KPNA Kapena powierzchnię produkcyjną i administracyjną o wielkości $700 \mathrm{~m}^{2}$ i zatrudniała 25 osób wywodzących się ze słupskiego przedsiębiorstwa. W marcu 1994 r. rozpoczęto montaż kompletnych autobusów oraz produkcję podwozi do autobusów turystycznych. W następnych latach uruchomiono montaż ciągników siodłowych. W 2003 r. koncern Scania AB odkupił od przedsiębiorstwa Kapena S.A. akcje spółki Scania-Kapena S.A., dzięki czemu 100\% tej spółki przeszło na własność koncernu. Wówczas zmieniono nazwę spółki na Scania Production Słupsk S.A. Przedsiębiorstwo Scania Production Słupsk S.A. wykupiło również ziemię i budynki należące do przedsiębiorstwa Kapena. 


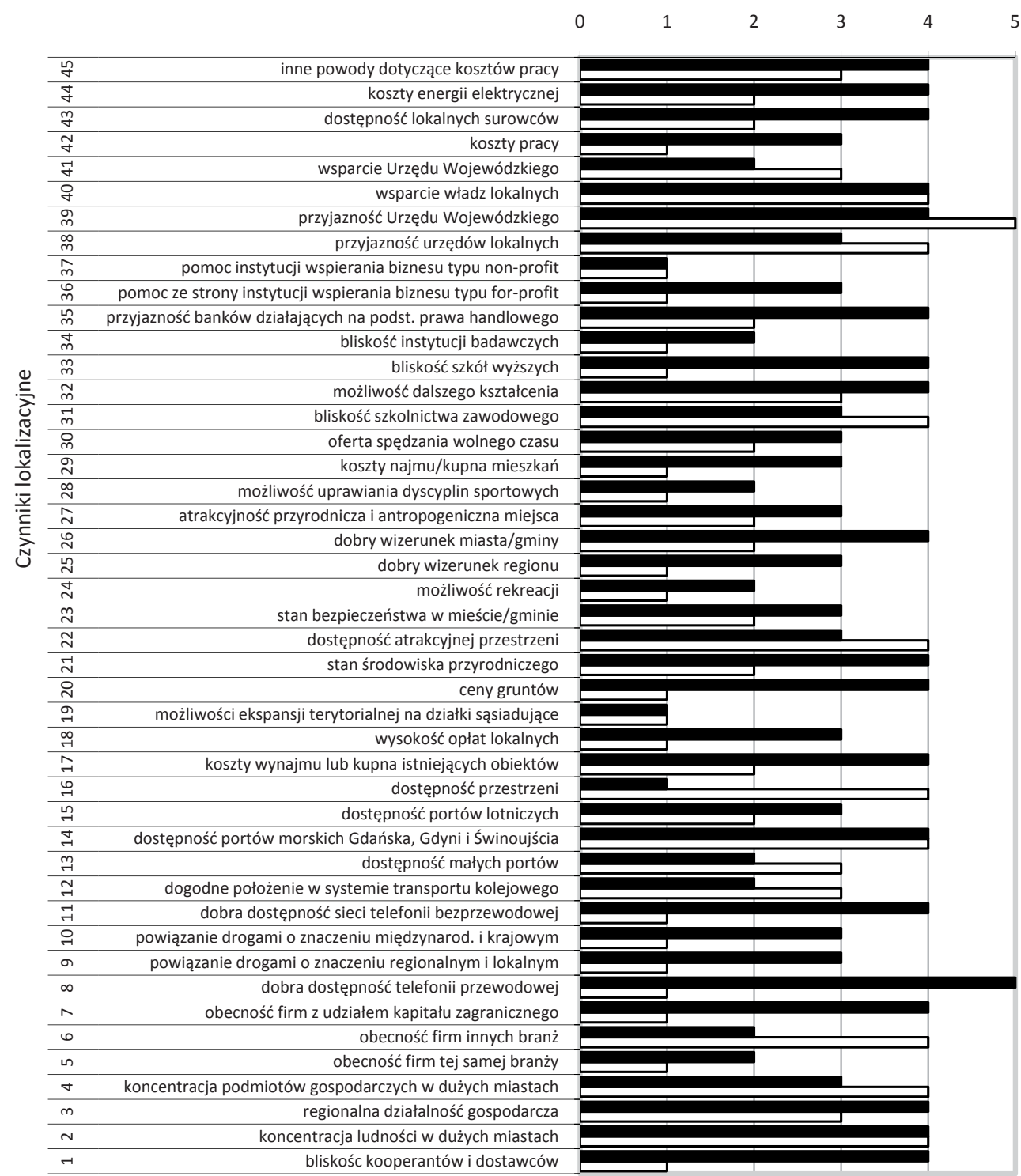

Ryc. 2. Preferencje lokalizacyjne przedsiębiorstwa Scania Production Słupsk S.A. w 1992 r. i 2007 r.

Źródło: opracowanie własne 


\section{ZAGADNIENIA STOSUNKÓW PRACY}

Jedną z najważniejszych cech każdego przedsiębiorstwa, będącąjednocześnie miarąjego rozwoju, jest zatrudnienie. Liczba pracujących w przedsiębiorstwie Scania Production Słupsk S.A. w zasadzie od momentu rozpoczęcia działalności aż do końca 2007 r. posiada tendencję wzrostową. Wzrost zatrudnienia wynikał przede wszystkim z rosnących możliwości produkcyjnych autobusów i podwozi. Nie bez znaczenia, w kontekście lokalnego rynku pracy, okazała się również opinia o warunkach pracy i wynagrodzeniu. Zakład postrzegany jest jako jeden z najlepszych lokalnych pracodawców (Słoniewska-Malitka 2006). Jak wynika z badań, mimo aktualnie odczuwanego spowolnienia gospodarczego ${ }^{5}$ Scania Production Słupsk S.A. przewiduje, iż w roku 2013 liczba pracujących będzie dwukrotnie wyższa od obecnej (ryc. 3).

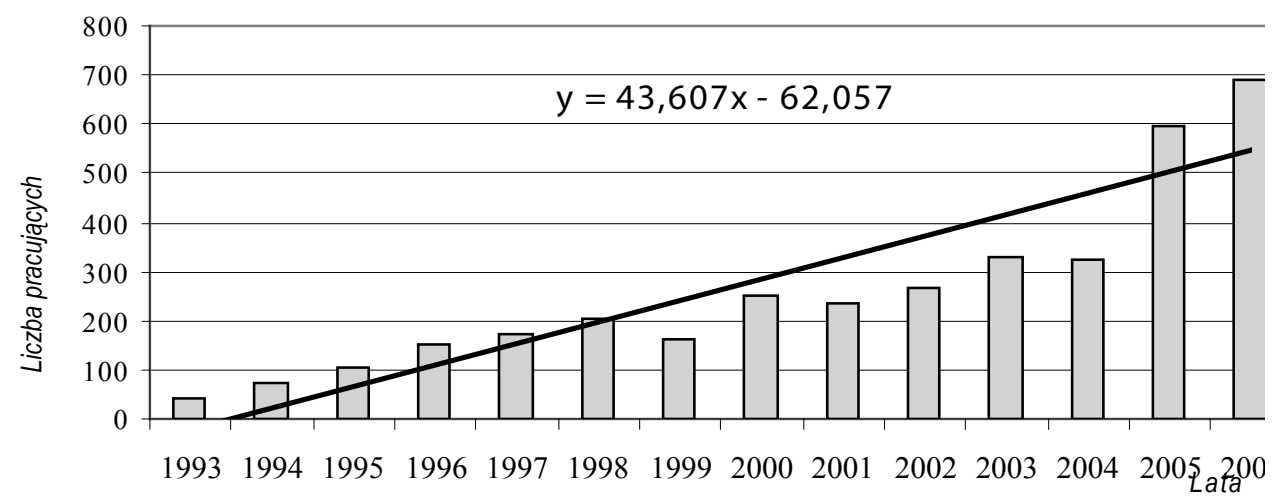

- linia trendu liniowego

Ryc. 3. Pracujący w Scania Production Słupsk S.A. w latach 1993-2007

Źródło: Scania Production Słupsk S.A. Sprawozdania DG-1 dla US, opracowanie własne

Tak dynamiczny wzrost zatrudnienia świadczy o szerokim rozwoju przedsiębiorstwa, w którym ze względu na specyfikę branżową 93\% zatrudnionych to mężczyźni. Należy nadmienić, że na skutek realizacji nowej strategii zatrudnienia, zakładającej przyjmowanie do pracy kandydatów przygotowanych już do pracy na określonym stanowisku, często zaawansowanym technologicznie, jak również wysokich wymagań merytorycznych i organizacyjnych prawie $80 \%$ ogółu pracujących stanowią osoby ze stażem pracy do lat 5, a około $40 \%$ pracujących to osoby w przedziale wiekowym 26-35 lat.

Zaawansowany proces montażowy, międzynarodowe powiązania organizacyjne, nowoczesne formy zarządzania, a czasem także doświadczenie i kompetencje powodują, że pracujący w przedsiębiorstwie to nie tylko mieszkańcy Słupska, ci bowiem stanowią 65,7\% ogółu pracujących. Z pozostałej część załogi (34,3\%), najliczniejszą grupę dojeżdżających stanowią osoby zamieszkałe w powiecie słupskim, sławieńskim, koszalińskim, i lęborskim,

5 W lutym 2009 r. firma zdecydowała o zwolnieniu z pracy w fabryce w Słupsku 108 osób. Bezpośrednim powodem był spadek zamówień na produkowane autobusy. 
gdzie czas dojazdu do pracy z reguły nie przekracza 60 minut. Istnieje jednak niewielka grupa osób (około 10 pracowników), która zamieszkuje bardziej odległe od Słupska miejscowości powiatów tczewskiego, malborskiego, kościerskiego oraz szczecineckiego i drawskiego. Wobec powyższego można zaryzykować stwierdzenie, że Scania Production Słupsk S.A., jest ważnym miejscem pracy nie tylko w mieście czy regionie, ale nawet w skali międzyregionalnej.

Realizowany w przedsiębiorstwie zintegrowany system zarządzania wszystkimi swoimi zasobami, w tym najważniejszym z nich - kapitałem ludzkim, powoduje, że kultura organizacyjna i szkoleniowa jest bardzo dobrze rozwinięta. Z racji przynależności do szwedzkiego koncernu językiem obowiązującym na wszystkich wydziałach fabryki (oprócz języka polskiego) jest język angielski. Dowodem są wszelkiego rodzaju dokumenty sporządzane w języku polskim i angielskim. Wymóg znajomości języka angielskiego jest szczególnie restrykcyjnie przestrzegany wśród kadry kierowniczej, chociaż kursy językowe są organizowane dla wszystkich pracowników, zarówno produkcyjnych, jak i nieprodukcyjnych.

\section{WIELKOŚĆ I ASORTYMENT PRODUKCJI ORAZ ZAOPATRZENIE W MATERIAŁY}

W 1993 r. rozpoczęto w Słupsku montaż samochodów ciężarowych, a rok później produkcję autobusów miejskich. Pod koniec roku 2001 Scania podjęła decyzje o reorganizacji produkcji autobusów na rynku europejskim, co w pierwszej kolejności wpłynęło na zamknięcie oddziału produkcyjnego w Danii, a w drugiej kolejności przyniosło napływ kapitału do fabryk w Katrineholm (Szwecja), w Sankt Petersburgu (Rosja) oraz w Słupsku. W lipcu 2002 r. zaprzestano w Słupsku montażu samochodów ciężarowych w celu zintensyfikowania produkcji autobusów miejskich. Łącznie w latach 1992-2002 wyprodukowano w Słupsku 7936 ciężarówek marki Scania, z których 4589 sztuk (57,8\%) zostało sprzedanych na rynku krajowym, a pozostałe 3347 wyeksportowano do Niemiec i Czech (ryc. 4).

Od 2002 r. słupski zakład specjalizuje się w produkcji autobusów, a od 2006 podwozi autobusowych pod dalszą zabudowę. W okresie od 2002 do 2007 produkcja autobusów wzrosła ponadczterokrotnie i w latach 2006-2007 osiagnęła poziom 470-480 sztuk rocznie. Produkcja podwozi w liczbie 440-500 rocznie jest realizowana pod własne zamówienia (około 60\%) oraz na eksport do Anglii i Hiszpanii. Nie jest to jednak produkcja stabilna i mimo że w 2007 r. liczba wyprodukowanych podwozi przewyższyła liczbę autobusów, to produkcja podwozi jest ciagle traktowana jako działalność dodatkowa i jako taka była realizowana już wcześniej w latach 1995-2000 oraz 2002 r. 


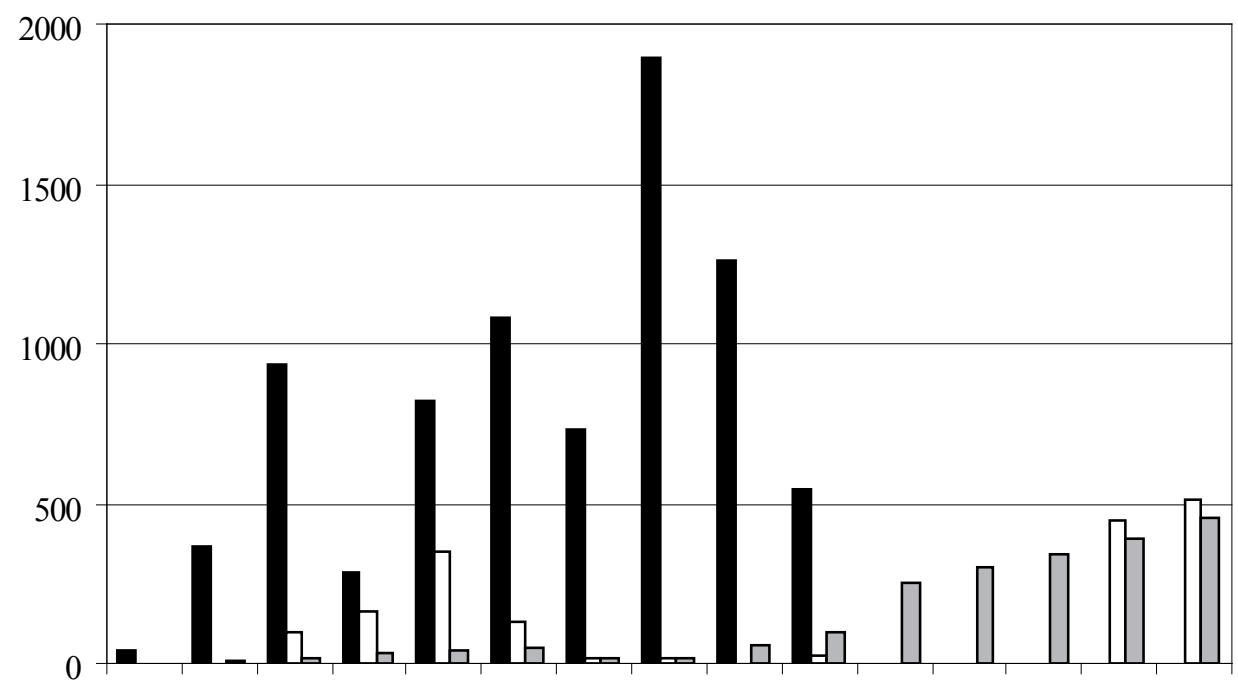

199319941995199619971998199920002001200220032004200520062007

- Ciągniki siodłowe $\square$ Podwozia autobusowe $\square$ Autobusy miejskie

Ryc. 4. Produkcja według asortymentu w przedsiębiorstwie Scania Production Słupsk S.A. w latach 1993-2007

Źródło: Scania Production Słupsk S.A., Wielkość produkcji - raporty roczne

Dzięki powiązaniom organizacyjnym koncernu Scania AB wyprodukowane w Słupsku autobusy sprzedawane są do Szwecji do Scania Omni AB, a za ich pośrednictwem dostarczane są do dealerów na terenie całej Europy (tab. 2).

Do najbardziej znanych ośrodków miejskich, do których sprzedawane były lub są autobusy wyprodukowane przez Scania Production Słupsk S.A., należą: Wenecja, Amsterdam, Londyn, Paryż, Sztokholm, Kopenhaga i Tallin. W Polsce użytkownikami autobusów ze Słupska są przedsiębiorstwa komunikacji miejskiej w Krakowie, Malborku, Olsztynie, Słupsku, Koninie, Gdyni oraz Grodzisku Mazowieckim. Wytwarzane autobusy napędzane gazem (CNG) eksploatowane są we Włoszech i na Islandii, a zasilane etanolem w Szwecji.

Jak wynika z analizy, w okresie ostatnich sześciu lat Wielka Brytania stała się głównym odbiorcą autobusów wyprodukowanych przez Scania Production Słupsk S.A. W latach 2003-2008 na rynek brytyjski dostarczono 512 pojazdów, co stanowi 26,2\% ogółu wyprodukowanych w tym okresie autobusów. Następne miejsca pod względem wielkości sprzedaży stanowią rynki Szwecji (19,0 \%), Włoch $(12,6 \%)$ oraz Francji $(11,4 \%)$. Udział rynku polskiego w sprzedaży autobusów wyniósł w badanym okresie $7,4 \%$, co sytuowało Polskę na piątym miejscu.

Należy nadmienić, że wielkość produkcji autobusów i podwozi autobusowych w Słupsku jest uzależniona od decyzji podejmowanych w Szwecji. Dotyczy to nie tylko decyzji na poziomie koncernu, ale również uzależnione jest od wyspecjalizowanej w sprzedaży spółki Scania Omni AB z siedzibą w Södertälje. 
Tab. 2. Sprzedaż autobusów według krajów dostarczenia w latach 2003-2008*

\begin{tabular}{|l|r|r|r|r|r|r|r|}
\hline \multicolumn{1}{|c|}{ Odbiorca } & $\mathbf{2 0 0 3}$ & $\mathbf{2 0 0 4}$ & $\mathbf{2 0 0 5}$ & $\mathbf{2 0 0 6}$ & $\mathbf{2 0 0 7}$ & $\mathbf{2 0 0 8}$ & Razem \\
\hline Wielka Brytania & 79 & 71 & 41 & 83 & 179 & 59 & 512 \\
\hline Szwecja & 49 & 23 & 104 & 108 & 44 & 43 & 371 \\
\hline Włochy & 23 & 69 & 62 & 58 & 23 & 10 & 245 \\
\hline Francja & 31 & 29 & 22 & 15 & 81 & 44 & 222 \\
\hline Polska & 13 & - & 10 & 9 & 61 & 52 & 145 \\
\hline Dania & 11 & 57 & 50 & 16 & - & 3 & 137 \\
\hline Norwegia & - & - & - & 64 & 12 & 38 & 114 \\
\hline Holandia & - & 2 & 44 & 24 & - & - & 70 \\
\hline Estonia & - & - & - & 15 & 40 & 10 & 65 \\
\hline Niemcy & - & 7 & 3 & 7 & 14 & 3 & 34 \\
\hline Luksemburg & 10 & 8 & - & - & - & - & 18 \\
\hline Islandia & 4 & 4 & 2 & - & - & - & 10 \\
\hline Korea & 2 & - & - & - & - & - & 2 \\
\hline Cypr & - & - & - & - & 2 & - & 2 \\
\hline Belgia & - & - & - & 1 & 1 & - & 2 \\
\hline Rosja & - & - & 1 & & - & - & 1 \\
\hline Chiny & - & - & - & - & 1 & - & 1 \\
\hline Razem & 222 & 270 & 339 & 400 & 458 & 262 & 1951 \\
\hline
\end{tabular}

* I-VI. 2008

Źródło: Scania Production Słupsk S.A. Dział księgowości, Zestawienie kierunków sprzedaży autobusów. Stan na czerwiec 2008 r.

Ważnym elementem funkcjonowania każdego przedsiębiorstwa jest zaopatrzenie w materiały do produkcji oraz pozyskiwanie dostawców tych materiałów. Dostawcy tworząc więzi pasywne przedsiębiorstwa mogą stanowić o kosztach produkcji, a w konsekwencji wpływać na konkurencyjność oferty.

Ze względu na specyfikę prowadzonej działalności produkcyjnej liczba materiałów wykorzystywanych przy produkcji autobusów i podwozi jest bardzo duża. Zarówno autobusy, jak i podwozia są produkowane przez fabrykę w Słupsku od podstaw, to powoduje, że potrzebuje ona znacznej liczby bardzo zróżnicowanej oferty kooperantów (tab. 3).

Większość dostawców Scania Production Słupsk S.A. stanowią dostawcy krajowi $(58,9 \%)$. Znaczące miejsce w dostawach zajmuje również Szwecja (16,9\%). Wśród pozostałych na uwagę zasługują kooperanci z Danii $(5,4 \%)$, Niemiec $(4,8 \%)$ oraz Wielkiej Brytanii $(3,9 \%)$. Pozostali dostawcy wywodzący się z szesnastu innych państw europejskich stanowią zaledwie 10,1\% ogółu. Warto jednak dodać, że najbardziej zaawansowane technologicznie podzespoły (np. systemy napędowe oraz osprzęt elektroniczny) dostarczane są przez dostawców zagranicznych głównie ze Szwecji lub Niemiec, natomiast polscy dostawcy oferują produkty o niższym poziomie technicznym oraz elementy wykorzystywane do kompletacji. 
Zatem struktura wielkościowa kraju pochodzenia dostawców nie przekłada się na ich rolę i znaczenie w procesie montażowym.

Tab. 3. Lokalizacja dostawców części do produkcji autobusów i podwozi według państw w 2007 r.

\begin{tabular}{|c|c|c|}
\hline \multirow{2}{*}{ Siedziba dostawcy } & \multicolumn{2}{|c|}{ Dostawcy } \\
\hline & w liczbach bezwzględnych & $\mathrm{w} \%$ \\
\hline Polska & 1104 & 58,9 \\
\hline Szwecja & 353 & 16,9 \\
\hline Dania & 98 & 5,4 \\
\hline Niemcy & 88 & 4,8 \\
\hline Wielka Brytania & 72 & 3,9 \\
\hline Francja & 40 & 2,3 \\
\hline Włochy & 27 & 1,5 \\
\hline Estonia & 22 & 1,3 \\
\hline Finlandia & 21 & 1,2 \\
\hline Holandia & 18 & 1,1 \\
\hline Norwegia & 11 & 0,7 \\
\hline Szwajcaria & 7 & 0,4 \\
\hline Belgia & 4 & 0,3 \\
\hline Hiszpania & 4 & 0,3 \\
\hline Austria & 3 & 0,2 \\
\hline Rosja & 3 & 0,2 \\
\hline Czechy & 2 & 0,2 \\
\hline Irlandia & 1 & 0,1 \\
\hline Litwa & 1 & 0,1 \\
\hline Łotwa & 1 & 0,1 \\
\hline Węgry & 1 & 0,1 \\
\hline Ogółem & 1881 & 100,0 \\
\hline
\end{tabular}

Źródło: Scania Production Słupsk S.A. Dział księgowości, Lista kooperantów. Stan na grudzień 2007

\section{Podsumowanie}

Omawiane przedsiębiorstwo Scania Production Słupsk S.A. jest jedynym w Polsce zakładem produkcyjnym szwedzkiego koncernu Scania AB. Nie można więc odnieść tego przypadku bezpośrednio do innego. Niemniej na uwagę zasługuje fakt, że dotychczasowe funkcjonowanie spółki było i jest silnie uzależnione od decyzji podejmowanych w siedzibie koncernu w Södertälje. Dotyczy to w zasadzie wszystkich sfer działalności, a w szczególności struktury zatrudnienia, struktury produkcji oraz więzi pasywnych i aktywnych słupskiej fabryki. Mimo tak silnego uzależnienia decyzyjnego lub właśnie dlatego przedsiębiorstwo działa sprawnie. Jak wynika z przedstawionych danych, w badanym okresie rosła liczba pracujących oraz wielkość produkcji sprzedanej. Można więc także przyjąć, że i rentowność spółki oraz wypracowany zysk były dodatnie. 
Można przyjąć, że wprowadzenie szwedzkiego modelu zarządzania i organizacji procesu produkcji w połączeniu z przygotowaną do tego i rozumiejąca zasady funkcjonowania modelu polską załogą przyniosło ewidentny sukces rynkowy. Na szczególną uwagę zasługuje szybkość reakcji koncernu na zmieniające się otoczenie, które niemalże natychmiast znajduje odzwierciedlenie w działalności także słupskiego przedsiębiorstwa. Na skutek nie tylko kompresji czasu i przestrzeni, będących widoczną oznaką zachodzących procesów globalizacyjnych, ale również doświadczeń w zakresie marketingu, zarządzania, technologii oraz polityki finansowej w zasadzie nie dochodzi w koncernie do opóźnienia diagnostycznego i decyzyjnego.

Przykładem takich właśnie działań może być sytuacja z lutego 2009 r., kiedy to na skutek spowolnienia gospodarczego, wywołanego kryzysem ogólnoświatowym, spadł popyt na autobusy. W koncernie Scania AB natychmiast podjęto plan stabilizacji krótkookresowej, który niemal natychmiast został wdrożony w Słupsku, czego przejawem były zwolnienia grupowe. Po upływie trzech miesięcy sytuacja na rynku motoryzacyjnym ustabilizowała się i zgodnie z decyzją ze Szwecji Scania Production Słupsk S.A. rozpoczęła nabór pracowników.

Można więc przyjąć, że swoistą ceną za względną stabilizację ekonomiczną przedsiębiorstwa jest jego podległość decyzyjna, ale czy taka zależność niesie same korzyści?

\section{Literatura}

Czapliński P., Musiałek M., 2007, Motywy podjęcia działalności gospodarczej w podregionie stupskim na tle uwarunkowań lokalnych i regionalnych (na wybranych przyktadach), [w:] Teoretyczne i praktyczne aspekty rozwoju regionalnego, red. E. Janowicz, Wyższa Hanzeatycka Szkoła Zarządzania w Słupsku, Słupsk, s. 69-81.

Gierańczyk W., Stańczyk A., 2003, Korporacje międzynarodowe w przestrzeni globalnej, [w:] Ksztattowanie się struktur przemystowych, red. Z. Zioło, Z. Makieła, Prace Komisji Geografii Przemysłu PTG nr 5, Wydawnictwo Naukowe Akademii Pedagogicznej, Warszawa-Kraków, s. 73-76.

Pakulska T., Poniatowska-Jaksch M., 2009, Korporacje transnarodowe a globalne pozyskiwanie zasobów, Wydawnictwo SGH, Warszawa.

Scania Annual Report, 2006, Scania CV AB, Södertälje Sweden 2007.

Słoniewska-Malitka B., 2006, Geneza Scanii Production Stupsk S.A., Zbliżenia, nr 2.

Stryjakiewicz T., 1999, Adaptacja przestrzenna przemystu $w$ Polsce $w$ warunkach transformacji, Wydawnictwo UAM, Poznań.

Zorska A., 2006, Korporacje transnarodowe, Polskie Wydawnictwo Ekonomiczne, Warszawa.

\section{Signs of globalization in production sphere exemplified by Scania Production Słupsk S.A.}

The article describes the structure of Scania as a global corporation. The company manufactures: city buses, coaches and heavy-load trucks. The article depicts the development of Scania in the world and mainly in Poland. We have described in detail the company from Słupsk - Scania Production Stupsk S.A. Mainly, employment figures and structures, production in numbers, as well as target markets. The part of work concerns the strategy of the company and the plans for further expansion.

dr Paweł Czapliński

Akademia Pomorska w Słupsku

somma@go2.pl 